\title{
Adherence ability of Pseudomonas aeruginosa to intestinal epithelium of Rabbit
}

\author{
*R.Z. Shinshal $\quad * *$ A.H. Al-Hamadani \\ *College of Girl education ** College of Veterinary Medicine \\ University of Mosul
}

Received

20/02/2007
Accepted

04/04/2007

\section{الخلاصة}

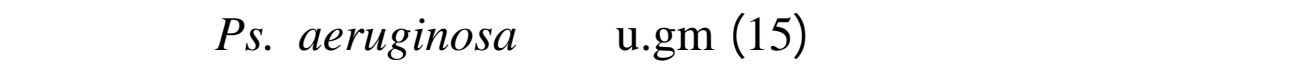
على الالتصاق بخلايا الغشاء الظهاري للأمعاء وقدرتها عل تمزيق حولجز الدفاع للأمعاء ضد

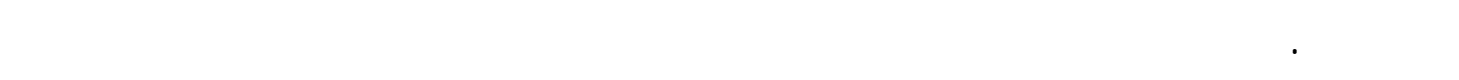

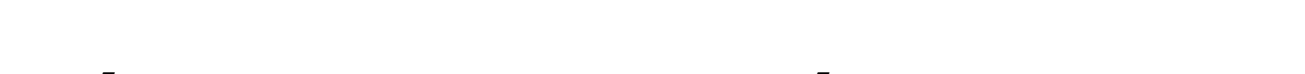

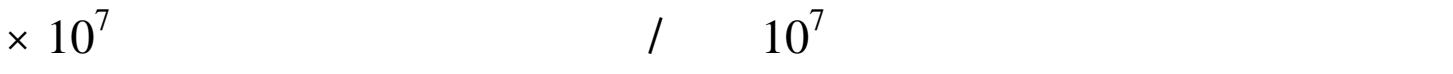

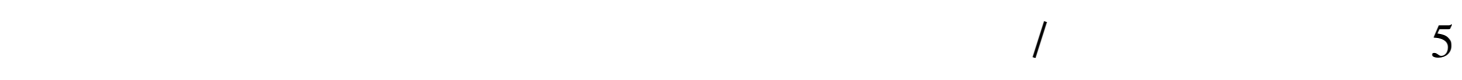
بينها وحدوث التمزق للحولجز الظهارية في الأمعاء.

\section{ABSTRACT}

This study investigated the adherence ability of fifteen isolates of Pseudomonas aeruginosa to intestinal epithelium, by inducing in vitro infection of incubating suspension of rabbits intestinal epithelium cells of $10^{7}$ cell/ml concentration with $5 \times 10^{7} \mathrm{cfu} / \mathrm{ml}$ suspension of $P$ s. aeruginosa and detect the occurrence of the adherence between them and the altering of function with the disrupt of the intestinal epithelial barrier.

\section{INTRODUCTION}

Pseudomonas aeruginosa considered as apportunistic pathogen which is the main cause of infections-related mortality among the critically ill these infections arise as a results gastrointestinal flora $(1,2)$. In spide of even in the absence of established extraintestinal infections and bacteremia, the presence of virulent strains of Ps. aeruginosa can be the major source of systemic septicemia and death amoung immunocompromised $(3,4)$. Among the many characteristics of highly successful pathogens that infect and harm their host is the ability to sense and responded to changes in their local microenviroment, that microenviroment state that topically signal a pathogen to responded with enhanced virulence are physicochemical properties such as changes in 
$\mathrm{PH}$, redox state and osmolarity of host cell contact itself has been shown to activate specific virulence regulatory pathway in several pathogens of clinical importance including Ps. aeruginosa $(5,6)$. Therefore the aim of this study is to investigate a major mechanism of the lethal effect of intestinal Ps. aeruginosa its ability to adhere and disrupt the intestinal epithelium barrier.

\section{MATERIALS AND METHODS}

\section{A) Bacterial isolates:}

15 isolates of Ps. aeruginosa was obtained from patients of different ages suffering from abdominal pain in Al-Zahrawii hospital from October to December 2006, inoculated on nutrient broth and brain heart infusion broth and incubated at $37 \mathrm{C}^{\circ}$ For $24 \mathrm{hr}$., , then kept at $4 \mathrm{C}^{\circ}$ For 4-6 days up to use.

\section{B) Intestinal epithelium cells}

These cells were obtained from adult rabbits (private breed) according to Knutton method $(7,8)$ by taking aparts of small intestine especially duodenum from secattered rabbits then these parts were washed externally and internally by cooled phosphate buffer solution [( $\mathrm{PH}: 7.2), 4 \mathrm{C}^{\circ}$ ], then opened longitudinally, dipping in cooled PBS for washing, scraping mucosal surface by scalple for obtaining the epithelium cells then transported in test tubes and centrifugated in cooled centrifuge at $1000 \mathrm{rpm}$ for $2 \mathrm{~min}$ in $4 \mathrm{C}^{\circ}$, the precipitin were taken and filtered through nylon peies for elimination the foreign tissues and crystals for obtaining the suspension of intestinal epithelium cells only. The concentration of cells was $10^{7}$ cell / ml.

\section{C) Adherence}

Adherence ability was done by using kuntton method (9) by adding $1 \mathrm{ml}$ suspension of extracted intestinal epithelium cells, the concentration was $10^{7} \mathrm{cell} / \mathrm{ml}$ to $2 \mathrm{ml}$ of $P$ s. aeruginosa bacterial suspension of $5 \times 10^{7} \mathrm{cfu} / \mathrm{ml}$ concentration (8), the mixture incubated for $1 \mathrm{hr}$ at $37 \mathrm{C}^{\circ}$, then the cells washing 3 times by PBS in cooled centrifuge at ( $1000 \mathrm{rpm}, 4 \mathrm{C}^{\circ}$ ) for $2 \mathrm{~min}$, then a few drop of sediment was put on glass slides, staining by Giemsa's stain for $30 \mathrm{~min}$ and exam with oil emersion lens under light microscope.

\section{RESULTS AND DISCUSSION}

The result of this study showed that the isolats of Ps. aeruginosa which are used is pathogenic and its pathogencity to intestinal epithelium involving the adherence and disruption of the epithelial barrier (picture $1,2)$. This result agreed with $(10,11,12,13)$.

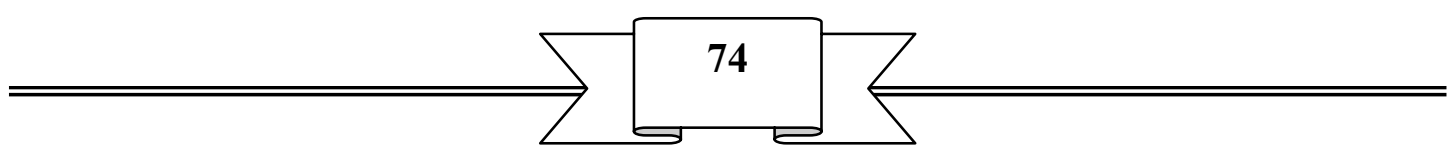




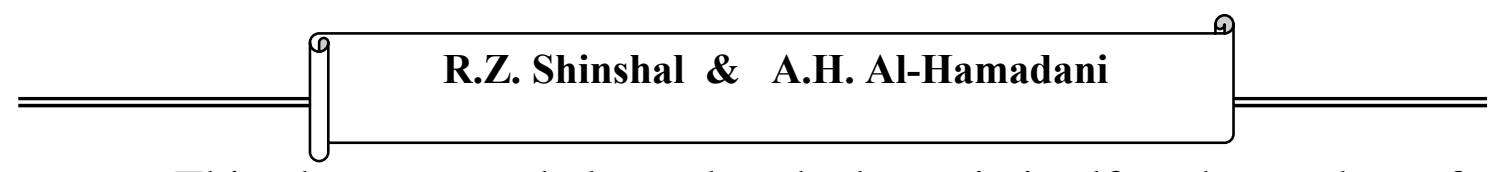

This phenomenon belonged to the bacteria itself or the product of the bacteria (enzymes or toxin) and these factors aid the appearance of this ability at the same time the epithelial cell resist the barrier dysregulating effects by release of mucus, Immunoglobulin A (IgA) and other defensins $(14,15)$. And there was apical side of intestinal epithelium is highly resistant to various cytolytic exoproducts of Ps. aeruginosa including exotoxin A and elastase $(16,17)$.

As the motility and adhesion to host cells are important factor to appear to predict virulence (18), so the bacteria are fully capable of change their virulence phenotype in direct response to host illness (19, 20).

Other study have identified a virulence - related attachment factor in Ps. aeruginosa, the PA-I lectin L adhesion, which plays a key role in adherence and distruption of the intestinal epithelial barrier, the PA - I lectin is capable of causing a significant permeability defect that allows paracellular flux of know cytotoxins of Ps. aeruginosa including exotoxin A and elastase (16), the PA - I lectin is 13.000 Da protein that is located within the cell cytoplasm when bacteria are grown in nutrient rich media under ideal laboratory conditions, yet under conditions of physiological stress, such as occurs within the intestinal tract following surgical injury, expression of the PA-I lectin is increased and the protein relocated to the bacterial cell surface $(21,22)$. Another study suggest that this organism behaves like a classic opportunist, switching virulence genes on and off in response to selected environmental condition, although it is well established that environmental condition such as $\mathrm{PH}$, redox state and nutrient composition can activate virulence gene expression in bacteria through a variety of membrane - bound biosensor kinases, (23). Also from the standpoint of the evolutionary fitness of the microbe, however, it is logical the pathogen might recognize the biochemistry of the host cell stress, because possessing a system that recognizes host susceptibility would allow for a more accurate assessment of the costs versus benefits of host invasion and cytotoxin effects of bacteria are often judged by their ability to adhere and alter the barrier cells, other shown that bacterial adherence alone can significantly alter the permeability of the intestinal epithelium to pro-inflammatory luminal macromolecules $(24,25)$.

The stress also consider an important factor for appearance adherence and disruption of the intestinal epithelial barrier by invading opportunistic microbial pathogens as Ps. aeruginosa $(26,27)$. Finally the centrifugation and washing by PBS deleate the cells non adheres after infection and pathogeneses this agreed with our results and (28). 

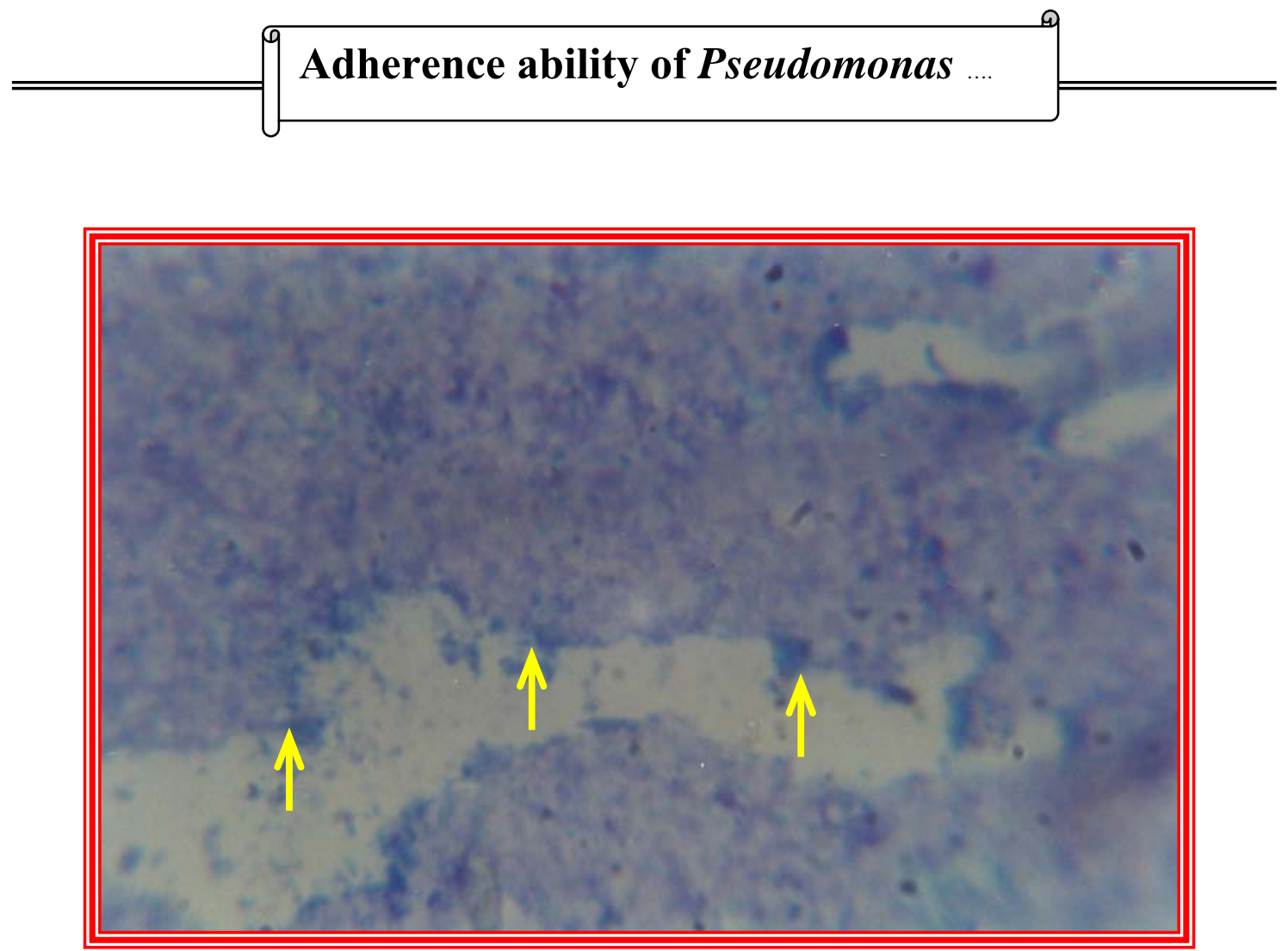

Figure 1:- Picture show intestinal epithelium involving the adherence and disruptions of the epithelium barrier in section of rabbit intestine, Giemsa's Stain, X1000.

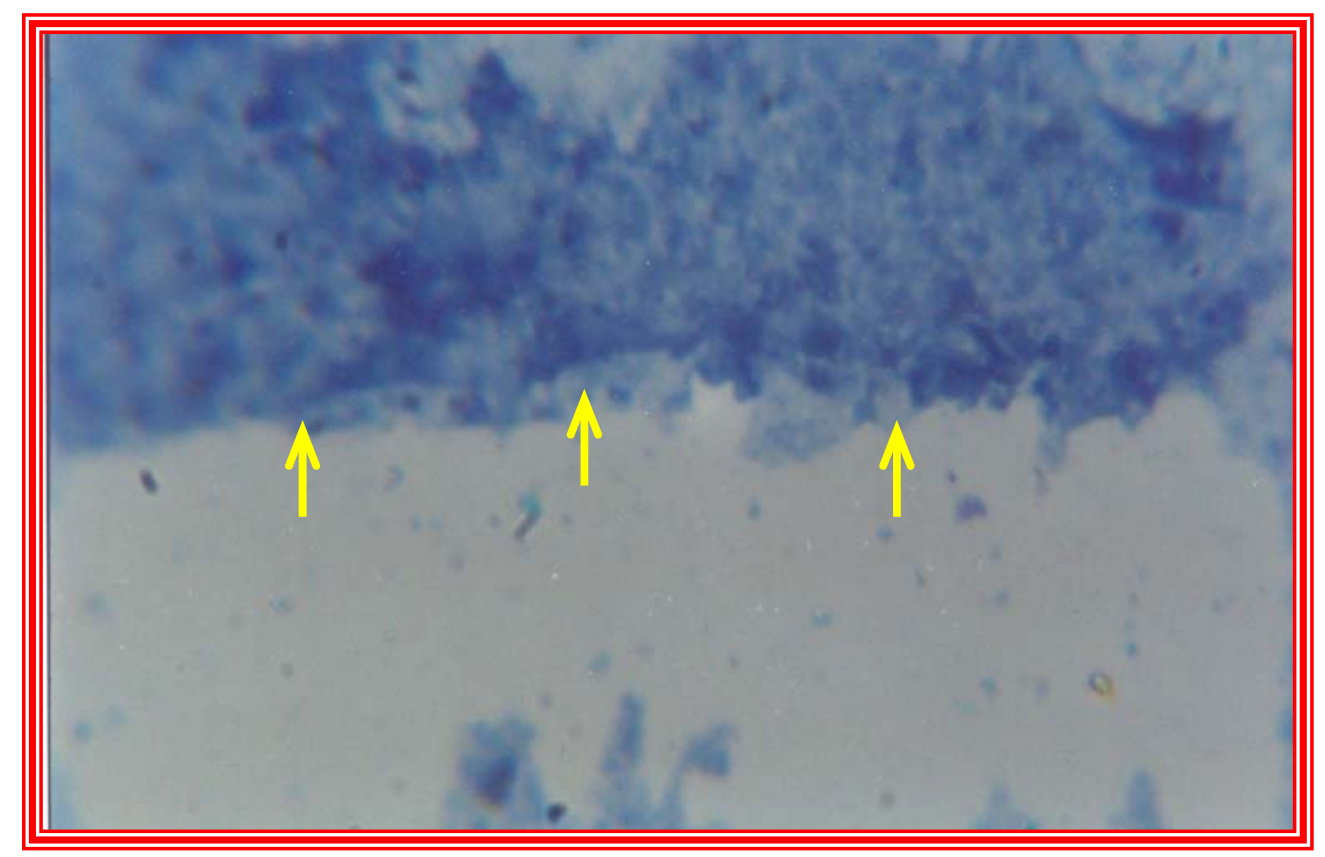

Figure 2:- Picture show intestinal epithelium involving the adherence and disruptions of the epithelium barrier in section of rabbit intestine, Giemsa's Stain, X1000.

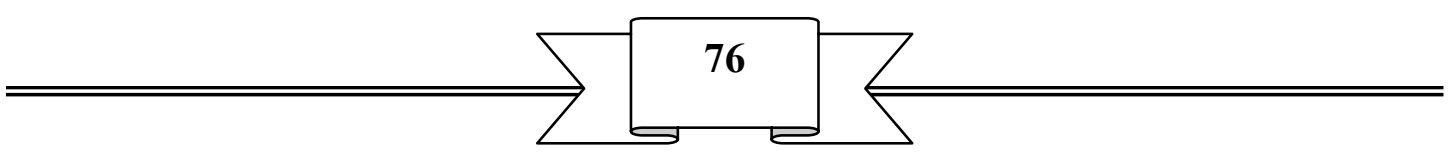




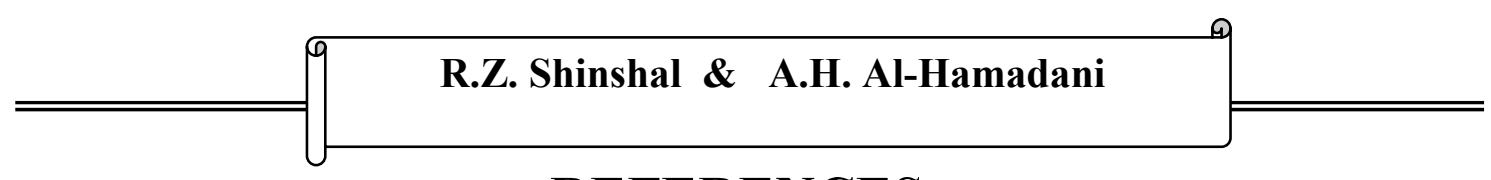

\section{REFERENCES}

1. Hirakata H, Izumikawa K, Yamaguchi H, Igim S, Toshiyuki Y, Scizunobu I, Nobuhiko F, Shigefumi M. Adherence to and pentration of human intestinal $\mathrm{CaCo} 2$ epithelial cell monolayers by Pseudomonas aeruginosa. Infect Immun, 1998 ; 66 (4):1748-1751.

2. Jonathan EK, Olga Z, Licheng WU, Yingmin W, Cindy B, Yimei C, James S, Jerrold RT, John CA. Components of intestinal epithelial hypoxia activate the virulence circuitry of Pseudomonas. Am J Physiol Gastrointest Liver Physiol, 2005 ; 288:G1048G1054.

3. Murono K, Hirano Y, Koyano S, Ito K, Fujieda K. Molecular comparison of bacterial isolates from blood with strain colonizing pharynx and intestine in immunocompromised patient with sepsis. J Med Microbiol. 2003; 52:537-530.

4. Hugonnet S, Harbarth S, Ferriere K, Ricou B, Suter P, Pittet D. Bacteremic sepsis in intensive care temporal trends in incidence, organ dysfunction and prognosis. Crit Care Med, 2003; 31:390394.

5. Berkes J, Viswanthan VK, Savkovic SD, Hecht G. Intestinal epithelial responses to entric pathogens : effects on the light Junction barrier, transport and inflammation. Gut, 2003; 52:439451.

6. Nazl A, Yang PC, Jury J, Howe K, Watson JL, Soderholm JD, Sherman PM, Perdue MH, Mckay DM. Epithelial under metabolic stress perceive commensal bacteria as a threat. Am J Pathol, 2003; 164:947-957.

7. Knutton S, Lioyd DR, Candy DCA, McNeish AS. Adhesion of Enterotoxigenic Escherichia coli to human small intestinal entrocytes. Ifect Immun, 1985; 48:251-259.

8. Al- Sarray D A Y. Effect of some factors on adherence of enterotoxigenic and uropathogenic Escherichia coli isolated from patients with diarrhea and urinary submitted to council of the college of science, University of Mosul. 2001.

9. Knutton S, McConnell MM, Rowe B, McNeish AS. Adhesion and ultrastructural properties of human Enterotoxigenic Escherichia coli producing colonization factor antigens III and IV. Infect Immun, 1989; 57: 3364-3371.

10. Marshall JC, Christou NV, Meakins JL. The gastrointestinal tract. The "undrained abscess" of multiple organ failure. Ann Surg, 1993; 218: 111-119.

11.Alverdy J, Holbrook C, Rocha F, Seiden L, Wu RL, Musch M, Chang EB, Ohman D, Suh S. Gut-derived sepsis occurs the right virulence genes meets the right host evidence for in vivo virulence

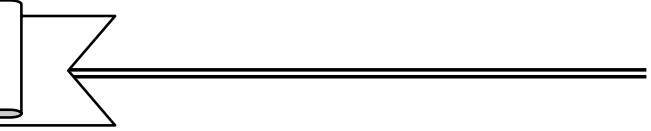


expression in Pseudomonas aeruginosa . Ann Surg, 2000; 232: 480-489.

12. Olanders K, Sun Z, Borjesson A, Dib M, Andersson E, Lasson A, Ohlsson T, Andersson R. the effect of intestinal ischemia and reperfusion injury on ICAM-1 expression endothelial barrier function, neutrophil tissue influx and protease inhibitor levels in rats shock, 2002; 18: 86-92.

13.Viswanathan VK, Sharma R, Hecht G. Microbes and their products-physiology effects upon mammalian mucosa. Adv Drug Delivery Res, 2004; 56: 727-762.

14. Gupta RA, Polk DB, Krishna U, Israel DA. Yan F, Dubois RN, Peek RM. Activation of peroxisome proliferators-activated receptor gamma suppresses nuclear factor Kappa B-mediated apoptosis induced by Helicobacter pylori in gastric epithelial cells. J Biol Chem, 2001; 31059-31066.

15.Karhausen J, Ibla JC, Colgan SP. Implication of hypoxia on mucosal barrier function cell. Mol Biol, 2003; 49:77-87.

16.Laughli RS, Musch MW, Hollbrook CJ, Rocha FM, Chang EB, Alverdy JC. The key role of Pseudomonas aeruginosa PA-I lectin on experimental gut-derived sepsis. Ann Surg, 2000; 133-142.

17.Wu L, Holbrook C, Zaborino O, Ploplys E, Rocha F, Pelham D, Chang E, Musch M, Alverdy J. Pseudomonas aeruginosa expresses a lethal virulence determinant, the PA-I lectin / adhesion is the intestinal tract of a stressed host, the role of epithelial cell contact and molecules of the aqoeum sensing signaling system. Ann Surg, 2003; 238:754-764.

18. Moller Ak, Leham MP, Conway T, Nijten PJ, Haan LA, Krogfelt KA, Cohen PS. An Escherichia coli MG1655 lipopolysaccharide deep-rough care mutant graw and survives in mouse cecal mucosa but fails to colonize the mouse large intestine. Infect Immun, 2003; 71:2142-2152.

19.Donnell Sc, Taylor N, VanSaene HK, Magnall VL, Pierro A, Lioyd DA. Infection rates in surgical neonates and infants receving parenteral nutrition : afive-year prospective study. J Hosp Infect, 2002; 52: 273-280.

20.Sun J, Hobert ME, Rao AS, Neish AS, Madara JL. Bacterial activation of B-catenin signaling in human epithelial. AM J Physiol Gastrointest Liver Physiol, 2004; 287: G220-G227.

21. Alverdy JC, Laughlin RS, Wu L. Influence of the critically ill state on host-pathogen interactions within the intestine : gut-derived sepsis redefined. Crit Care Med, 2003; 31: 598-607.

22.Wu l, Zaborina O, Zaborin A, Chang EB, Musch M, Holbrook C, Shapiro J, Turner JR, Wu G, Lee KY, Alverdy JC. High-

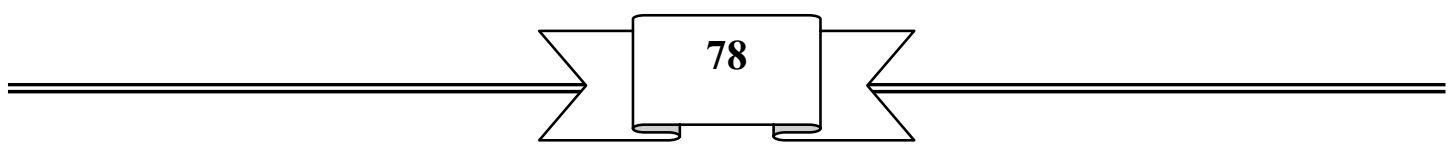




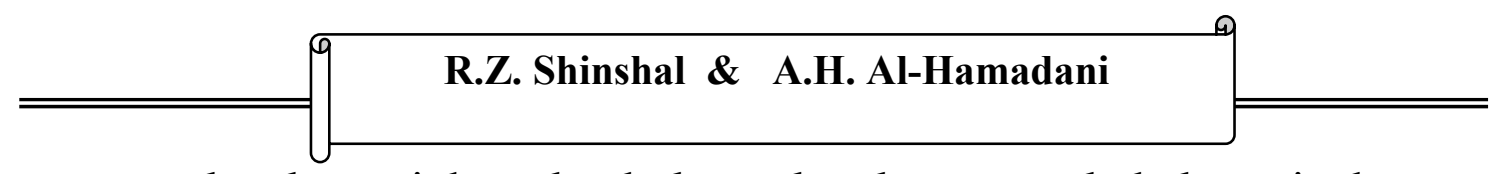

molecular-weight polyethylene glycol prevents lethal sepsis due to intestinal Pseudomonas aeruginosa. Gastoenterology, 2004; 126:488-498.

23.Xu J, Chiang HC, Bjursell Mk, Gordon JI. Message from a human gut symbiont : sensitivity is a prerequisites for sharing. Trends Microbiol, 2004; 12:21-28.

24.Spita J, Yuhan R, Koutsouris A. Enteropathogenic Escherichia coli adherence to intestinal epithelial monolayers diminishes barrier function. Am J Physiol, 1995; 268: (2pt1): G374-G379.

25.Spitz JC, Ghardi S, Taveras M. Characteristics of the intestinal epithelial barrier during dietary manipulation and glucocorticoid stress. Crit Care Med, 1996; 24: 635-641.

26. Shethe SR, Leckband D. Measurements of attractive forces between proteins and end-grafted polyethylene glycol chains. Proc Natl Acad Sci, 1997; 94: 8399-8404.

27.Lugea A, Salas A, Casalot J, Guarner F, Malagelada JR. Surface hydrophobicity of the rat colonic mucosa is adefecsive barrier against macromolecules and toxins. Gu, 2000; 46:515-521.

28.Clark VL, Baviol PM. Bacterial pathogensis. Academic press, 1997; New York: 48-52. 